\title{
PEMAHAMAN KOSAKATA NAMA BENDA BAHASA MELAYU SUKADANA PADA SISWA SMA DI KECAMATAN SUKADANA
}

\author{
Firdaus Zar'in', Mellisa Jupitasari2 ${ }^{\text {** }}$ \\ firdauszarin999@gmail.com ${ }^{1}$,mellisajupitasari@fkip.untan.ac.id ${ }^{*}$ \\ Fakultas Keguruan dan Ilmu Pendidikan Universitas Muhammadiyah Pontianak ${ }^{1}$, Fakultas Keguruan dan \\ Ilmu Pendidikan Universitas Tanjungpura ${ }^{2}$
}

\begin{abstract}
ABSTRAK
Penelitian ini bertujuan menginventarisasikan kosakata nama benda bahasa Melayu Sukadana, mendeskripsikan pemahaman siswa terhadap kosakata nama benda bahasa Melayu Sukadana berdasarkan gender, dan mendeskripsikan pemahaman siswa terhadap kosakata nama benda bahasa Melayu Sukadana berdasarkan siswa berbahasa ibu bahasa Melayu Sukadana dan bukan berbahasa ibu bahasa Melayu Sukadana. Metode yang digunakan dalam penelitian ini adalah metode deskriptif kualitatif yang ditunjang dengan metode kuantitatif. Sumber data penelitian ini adalah 10\% populasi siswa SMA Negeri 1 Sukadana, yaitu 52 siswa. Hasil penelitian ini menghimpun 150 kosakata kata benda yang terdiri atas 23 kata hewan, 25 kata tumbuhan, 21 kata makanan, 25 kata mainan/permainan, 39 kata alat rumah tangga, dan 17 kata penyakit yang diteskan kepada 52 siswa SMA Negeri 1 Sukadana. Berdasarkan hasil tes mengenai pemahaman siswa terhadap kosakata kata benda, seluruh siswa dari total sampel tersebut hanya memahami 69\% kosakata nama benda bahasa Melayu Sukadana. Berdasarkan klasifikasi gender, siswa laki-laki memiliki pemahaman $71 \%$ dan siswa perempuan $68 \%$. Selanjutnya, siswa berbahasa ibu bahasa Melayu Sukadana memiliki pemahaman $72 \%$ terhadap kosakata tersebut, sedangkan siswa yang bukan berbahasa ibu bahasa Melayu memiliki pemahaman sekitar $63 \%$.
\end{abstract}

Kata-kata Kunci : Pemahaman kosakata nama benda, Melayu Sukadana, Siswa SMA

\section{UNDERSTANDING NOUN VOCABULARY SUKADANA MALAY LANGUAGE HIGH SCHOOL STUDENTS IN SUKADANA DISTRICT}

\begin{abstract}
This research aims to inventory Sukadana Malay noun vocabulary, describe students 'understanding of Sukadana Malay noun vocabulary based on gender, and describe students' understanding of Sukadana Malay noun vocabulary based on Sukadana Malay mother tongue students and not Malay mother tongue Sukadana. The method used in this research is descriptive qualitative method supported by quantitative methods. The data source of this study was $10 \%$ of the population of students of SMA Negeri 1 Sukadana, namely 52 students. The results of this study collected 150 noun vocabularies consisting of 23 animal words, 25 plant words, 21 food words, 25 toy / game words, 39 household appliance words, and 17 disease words that were tested on 52 students of SMA Negeri 1 Sukadana. Based on the test results regarding students' understanding of noun vocabulary, all students from the total sample only understood 69\% of Sukadana Malay noun vocabulary. Based on gender classification, male students have an understanding of $71 \%$ and $68 \%$ female students. Furthermore, Sukadana Malay mother-language students have an understanding of $72 \%$ of the vocabulary, while students who do not speak Malay mother tongue have an understanding of around $63 \%$.
\end{abstract}

Keywords: Understanding noun vocabulary, Sukadana Malay, High School Students

Jurnal Elektronik WACANA ETNIK - Vol 9 No 2, 2020, (93 - 101) p ISSN 2089-8746, e ISSN 2302-7142 


\section{PENGANTAR}

Bahasa merupakan alat pemersatu yang digunakan untuk berkomunikasi sehari-sehari. Bahasa juga digunakan untuk menyalurkan ide, gagasan, saran, serta perasaan terhadap manusia satu ke manusia lain. Oleh karena itu, fungsi bahasa sangat urgen dalam berkehidupan sosial.

Selain bahasa Indonesia, Indonesia memiliki beratus-ratus bahasa daerah yang tersebar di seluruh penjuru daerah Indonesia. Bahasa daerah menjadi bahasa sehari-hari yang digunakan oleh masyarakat di daerah tertentu untuk berkomunikasi dan bersosialisasi. Namun, faktanya arus globalisasi membuat penggunaan dan pemahaman mengenai bahasa daerah semakin berkurang. Apabila hal ini terus terjadi tentu menyebabkan bahasa daerah tersebut akan punah.

Banyak faktor yang menyebabkan tergerusnya bahasa daerah (Tondo, 2009:284), yaitu faktor pengaruh bahasa mayoritas di mana bahasa daerah tersebut digunakan, kondisi masyarakat penuturnya yang bilingual atau bahkan multilingual, globalisasai, migrasi (migration), perkawinan antaretnik (intermarriage), bencana alam dan musibah juga dapat turut menjadi penyebab kepunahan sebuah bahasa, kurangnya penghargaan terhadap bahasa etnik sendiri, kurangnya intensitas komunikasi berbahasa daerah dalam berbagai ranah khususnya dalam ranah rumah tangga, faktor ekonomi, dan bahasa Indonesia.

Hal yang paling utama dan menjadi penyebab tergerusnya bahasa daerah ialah penurunan secara dariastis jumlah penutur aktif. Pengabaian penggunaan bahasa daerah oleh penutur usia muda juga merupakan gejala sebuah bahasa akan mengalami kepunahan. Asumsi umum memperlihatkan bahwa dewasa ini generasi muda tidak cakap lagi menggunakan bahasa daerah mereka masing-masing. Kebanyakan hanya menguasai secara pasif. Mereka mengerti dengan bahasa daerah mereka, tetapi tidak fasih berbicara dengan bahasa tersebut. Jika keadaan seperti ini terus berlanjut, bukan tidak mungkin beberapa tahun mendatang akan semakin banyak bahasa daerah yang pada akhirnya punah terkikis zaman. Oleh karena itu, tidak berlebihan jika bangsa Indonesia sudah saatnya segera melakukan berbagai upaya pelindungan bahasa. Kita berharap bahwa upaya tersebut akan memberikan sumbangan signifikan dalam upaya melestarikan dan mengelola bahasa sebagai kekayaan dan kekuatan untuk memperkukuh Negara Kesatuan Republik Indonesia (NKRI).

Berdasarkan penjelasan di atas, upaya perlindungan bahasa daerah juga perlu dilakukan pada bahasa Melayu Sukadana. Bahasa Melayu Sukadana merupakan bahasa daerah yang digunakan masyarakat Melayu Sukadana dalam berkomunikasi sehari-hari. Bahasa yang memiliki banyak penutur di wilayah Sukadana, Kabupaten Kayong Utara ini tidak menutup kemungkinan sedikit demi sedikit juga menghilang apabila sudah jarang yang menuturkan. Terlebih banyak faktor yang dapat menyebabkan tergerusnya bahasa daerah ini terutama bagi penutur muda.

Salah satu upaya yang dapat dilakukan sebagai upaya perlindungan bahasa daerah khususnya bahasa Melayu Sukadana ialah melakukan proses inventarisasi kosakata bahasa Melayu Sukadana. Banyak sekali jenis-jenis kosakata, namun kosakata yang dekat dengan kehidupan sehari-hari ialah kosakata nama benda. Fokus kosakata nama benda bahasa Melayu Sukadana ini dapat mencakup nama tumbuhan, hewan, alat-alat rumah tangga, alat-alat 
pertanian, makanan tradisional dan sebagainya. Berdasarkan penjelasan tersebut, hal yang dapat dilakukan untuk proses inventarisasi kosakata ini ialah membuat glosarium. Glosarium adalah daftar kata dalam bidang tertentu dengan penjelasannya (Kridalaksana, 2008:72). Glosarium nama benda ini dapat menjadi dokumen sebagai bentuk pelestarian bahasa tersebut. Melalui glosarium nama benda ini, kita juga dapat mengetahui pemahaman dan pengetahuan penutur usia muda. Mengingat penutur usia muda merupakan generasi penerus yang akan melestarikan bahasa daerah tersebut. Dalam hal ini, pemahaman siswa terhadap kosakata nama benda bahasa Melayu Sukadana dapat diketahui atau diuji melalui glosarium nama benda bahasa Melayu Sukadana yang telah disusun sebagai bentuk penginventarisasian bahasa Melayu Sukadana. Dengan mengetahui tingkat pemahaman siswa terhadap kosakata nama benda bahasa Melayu Sukadana, tentunya hal ini dapat menjadi tolok ukur untuk melakukan proses pemertahanan bahasa. Selain itu, penggunaan glosarium nama benda bahasa Melayu Sukadana juga masih dapat dijadikan suplemen teks pembelajaran bahasa Indonesia dan bahan ajar muatan lokal di jenjang pendidikan formal dan nonformal. Suplemen teks pembelajaran bahasa Indonesia ini dapat berupa media maupun sumber belajar yang menunjang kegiatan belajar berbasis teks pada pembelajaran bahasa Indonesia di kurikulum 2013. Maka dari itu, penelitian mengenai Pemahaman Kosakata Nama Benda Bahasa Melayu Sukadana pada Siswa SMA di Kecamatan Sukadana penting untuk dilakukan.

\section{KERANGKA TEORI DAN METODE}

Proses berbahasa antara penutur dan mitra tutur ini merupakan bagian dari disiplin ilmu sosiolinguistik. Sosiolinguistik adalah cabang ilmu linguistik yang bersifat interdisipliner dengan ilmu sosiologi dengan objek penelitian hubungan antara bahasa dengan faktor-faktor sosial di dalam masyarakat tutur (Chaer dan Leonie, 2010: $3-4)$.

Pemahaman penutur usia muda ini akan berkaitan dengan pemertahanan bahasa daerah. Dengan mengetahui tingkat pemahaman penutur usia muda, maka kita dapat melakukan antisipasi dengan melakukan tindakan pemertahanan bahasa. Pemertahanan bahasa daerah menjadi salah satu fenomena sekaligus langkah yang muncul di tengah polemik pergeseran bahasa daerah. Baik pemertahanan maupun pergeseran bahasa menjadi dua sisi mata uang. Keduanya hadir secara bersamaan. Artinya, terjadinya fenomena kebahasaan tersebut merupakan akibat dari hasil kolektif pilihan bahasa (language choice). Pilihan bahasa diartikan sebagai hasil dari proses memilih suatu bahasa yang dilakukan oleh masyarakat bahasa atau penutur multibahasawan. Artinya, penutur tersebut menguasai dua bahasa atau lebih sehingga dapat memilih bahasa yang digunakan dalam tindak tutur melalui variasi tunggal bahasa, alih kode, dan campur kode (Widianto, 2018:2).

Pergeseran bahasa juga muncul akibat sikap bahasa yang negatif dari penuturnya. Ada tiga ciri pokok perilaku atau sikap bahasa yang dijelaskan oleh Bawa (dalam Widianto, 2018:4). Ketiga ciri pokok sikap bahasa itu adalah (1) language loyality, yaitu sikap loyalitas/ kesetiaan terhadap bahasa, (2) language pride, yaitu sikap kebanggaan terhadap bahasa, dan (3) awareness of the norm, yaitu sikap sadar adanya norma bahasa. Konsep pemertahanan bahasa berawal dari pemahaman tentang kata tersebut. Konsep kebertahanan diartikan sebagai proses, cara, perbuatan mempertahankan. Pemertahanan bahasa terkait dengan faktor-faktor sosial dan psikologis, seperti kekuatan ikatan etnis, sistem nilai, pola permukiman, agama , sistem kekeluargaan,jenis kelamin, dan ekonomi. 
Pemertahanan bahasa adalah masyarakat tetap menggunakan bahasanya secara kolektif atau secara bersama-sama dalam ranah-ranah pemakaian tradisional (Widianto, 2018: 3).

Memahami bahasa berarti kita harus memahami kata. Pemakaian kata-kata dalam kegiatan berbahasa, pada umumya terbatas pada kata-kata yang sering digunakan. Kata senidarii berhubungan dengan leksikon. Kajian terhadap leksikon mencakup apa yang dimaksud dengan kata, strukturisasi kosakata, penggunaan dan penyimpanan kata, pembelajaran kata, sejarah dan evolusi kata (etimologi), hubungan antarkata, serta proses pembentukan kata pada suatu bahasa. Kosakata menurut Kridalaksana (2008:137) sama dengan leksikon. Leksikon adalah (1) komponen bahasa yang memuat semua informasi tentang makna dan pemakaian kata dalam bahasa; (2) kekayaan kata yang dimiliki seorang pembicara, penulis, atau suatu bahasa, (3) daftar kata yang disusun seperti kamus, tetapi dengan penjelasan singkat dan praktis. Dalam penggunaan sehari-hari, leksikon dianggap sebagai sinonim kamus atau kosakata. Sedikit membedakan leksikon dari perbendaharaan kata, yaitu leksikon mencakup komponen yang mengandung segala informasi tentang kata dalam suatu bahasa seperti perilaku semantis, sintaksis, morfologis, dan fonologisnya, sedangkan perbendaharaan kata lebih ditekankan pada kekayaan kata yang dimiliki seseorang atau sesuatu bahasa (Kridalaksan, 2008:142).

Kata benda merupakan nomina atau kata yang biasanya dapat berfungsi sebagai subyek atau obyek dari klausa. Kelas kata ini sering berpadanan dengan orang, benda, atau hal lain yang dibendakan dalam alam di luar bahasa (Kridalaksana, 2008:163). Berdasarkan segi semantis, kita dapat mengatakan bahwa nomina adalah kata yang mengacu pada manusia, binatang, benda, dan konsep atau pengertian. Kosakata juga dibagi dalam beberapa kelas kata. Satu di antaranya ialah nomina. Chaer (dalam Panggabean, 2017:9) mengatakan nomina adalah katakata yang dapat diikuti dengan frasa yang... atau yang sangat... Misalnya kata-kata: (1) jalan (yang bagus); (2) murid (yang rajin); (3) pemuda (yang sangat rajin). Ada tiga macam kata benda,yaitu:

(a) kata benda yang jumlahnya dapat dihitung sehingga di depan kata benda itu dapat diletakkan kata bantu bilangan,

(b) kata benda yang jumlahnya tak terhitung, dan

(c) kata benda yang menyatakan khas.

Penelitian ini menggunakan metode kualitatif dan kuantitatif. Metode kualitatif merupakan suatu pendekatan dalam melakukan penelitian yang berorientasi pada fenomena atau gejala yang bersifat alami (Susilana, 2007:1). Metode kuantitatif digunakan sebagai metode penunjang metode kualitatif. Metode penelitian kuantitatif merupakan suatu cara yang digunakan untuk menjawab masalah penelitian yang berkaitan dengan data berupa angka dan program statistik. Pada penelitian ini, metode kuantitatif digunakan hanya untuk menentukan sampel dan tingkatan persen pengetahuan anak terhadap pemahaman kosakata nama benda bahasa Melayu Sukadana. Selanjutnya, hasil penelitian tersebut dideskripsikan melalui metode kualitatif.

Metode kualitatif merupakan metode yang bersifat deskripsi. Nawawi (dalam Hidayat 2009:17) menyatakan bahwa, metode penelitian deskriptif mempunyai dua ciri pokok yaitu (1) memusatkan perhatian pada masalah-masalah yang ada pada saat penelitian dilakukan atau masalah yang bersifat aktual dan (2) mengambarkan fakta-fakta tentang masalah yang diselidiki sebagaimana adanya diiringi dengan interpretasi rasional. Metode 
deskriptif ini digunakan untuk menganalisis data yang telah didapatkan dari hasil pengumpulan data. Adapun teknik pengumpulan data dalam penelitian ini menggunakan teknik observasi, teknik studi dokumenter, teknik wawancara, dan teknik tes pemahaman.

\section{HASIL DAN PEMBAHASAN}

Hasil penelitian ini menghimpun 150 kosakata kata benda yang berasal dari Kamus Bahasa Melayu Sukadana-Indonesia dan data wawancara yang terdiri atas 23 kata hewan, 25 kata tumbuhan, 21 kata makanan, 25 kata mainan/permainan, 39 kata alat rumah tangga, dan 17 kata penyakit. Kosakata nama benda tersebut menjadi alat tes pemahaman siswa terhadap kosakata nama benda bahasa Melayu Sukadana. Sampel penelitian ini ialah 10\% populasi siswa SMA Negeri 1 Sukadana, yaitu 52 siswa SMA Negeri 1 Sukadana. Berdasarkan sampel penelitian tersebut, secara keseluruhan pemahaman siswa terhadap 150 kosakata nama benda hanya berkisar $69 \%$ dan $31 \%$ dari kosakata tersebut tidak diketahui. Selanjutnya, berikut di bawah ini inventarisasi kosakata nama benda bahasa Melayu Sukadana, dan pemetaan pemahaman siswa berdasarkan gender, yang berbahasa ibu bahasa Melayu Sukadana, serta yang bukan berbahasa ibu bahasa Melayu Sukadana.

\section{Inventarisasi Kosakata Nama Benda Bahasa Melayu Sukadana}

Inventarisasi kosakata nama benda bahasa Melayu Sukadana merupakan kumpulan 150 kosakata nama benda yang telah dikelompokkan berdasarkan kategori hewan, tumbuhan, makanan, mainan/permainan, alat rumah tangga, dan penyakit. Siswa diminta untuk mengelompokkan kosakata nama benda sesuai pemahamannya terhadap pengategorian kosakata kata benda tersebut. Berikut ini tabel inventarisasi kosakata nama benda bahasa Melayu Sukadana.

TABEL 1. Inventarisasi Kosakata Nama Benda Bahasa Melayu Sukadana

\begin{tabular}{|c|c|c|c|c|c|c|}
\hline No. & Hewan & Tumbuhan & Makanan & Mainan/permainan & $\begin{array}{l}\text { Alat rumah } \\
\text { tangga }\end{array}$ & Penyakit \\
\hline 1. & agas & badam badi & bloda & alang-alang & alga & Badi \\
\hline 2. & anai-anai & bakong & budu & campak lambong & bak & begok \\
\hline 3. & bari-bari & bebuas & cengkarok & cang-kacang panjang & belacuk & bikuk \\
\hline 4. & belangkas & ceko & cuco & cungket & belangak & bintel \\
\hline 5. & berok & cendawan & gamat & dengkak & belebas & burot \\
\hline 6. & canggai & cengkodok & getok & gaseng & beskom & gerumot \\
\hline 7. & gerunggong & ganjong & ipok-ipok & gasti & bopet & kanang \\
\hline 8. & jejentek & gelegundi & jempot-jempot & gembot & cawan & kayap \\
\hline 9. & kale & jelatang & kerie & gulik & centong & kelemumo \\
\hline 10. & kebenat & kecipe & kicak-kicak & injet-injet semot & cipe & kesambat \\
\hline 11. & kelelawa & kenange & kokyam & jengkal & cuek & koreng \\
\hline 12. & kekunang & ketipeng & lemang & kaki antu & dalong & kudes \\
\hline 13. & kelempiau & leban & lupes & keja lengke & dek & kutel \\
\hline 14. & kepindeng & leletop & nagesari & kelayang & geba & luge \\
\hline 15. & keriang & lepang & $\begin{array}{l}\text { penganan } \\
\text { pelite }\end{array}$ & kelempos & gerepu & medam palak \\
\hline 16. & mayong & pakes & putu buloh & ketepel & gerubok & panau \\
\hline 17. & mempangau & patawali & putu pireng & lungso-lungso & hazanah & restong \\
\hline 18. & pelandok & periak & randeseturi & maen bal & jenang & \\
\hline 19. & peleset & ribu-ribu & sagon & maen getak & katel & \\
\hline 20. & puyu & saguk belande & ungol-ungol & maen lidik & kelambu & \\
\hline
\end{tabular}




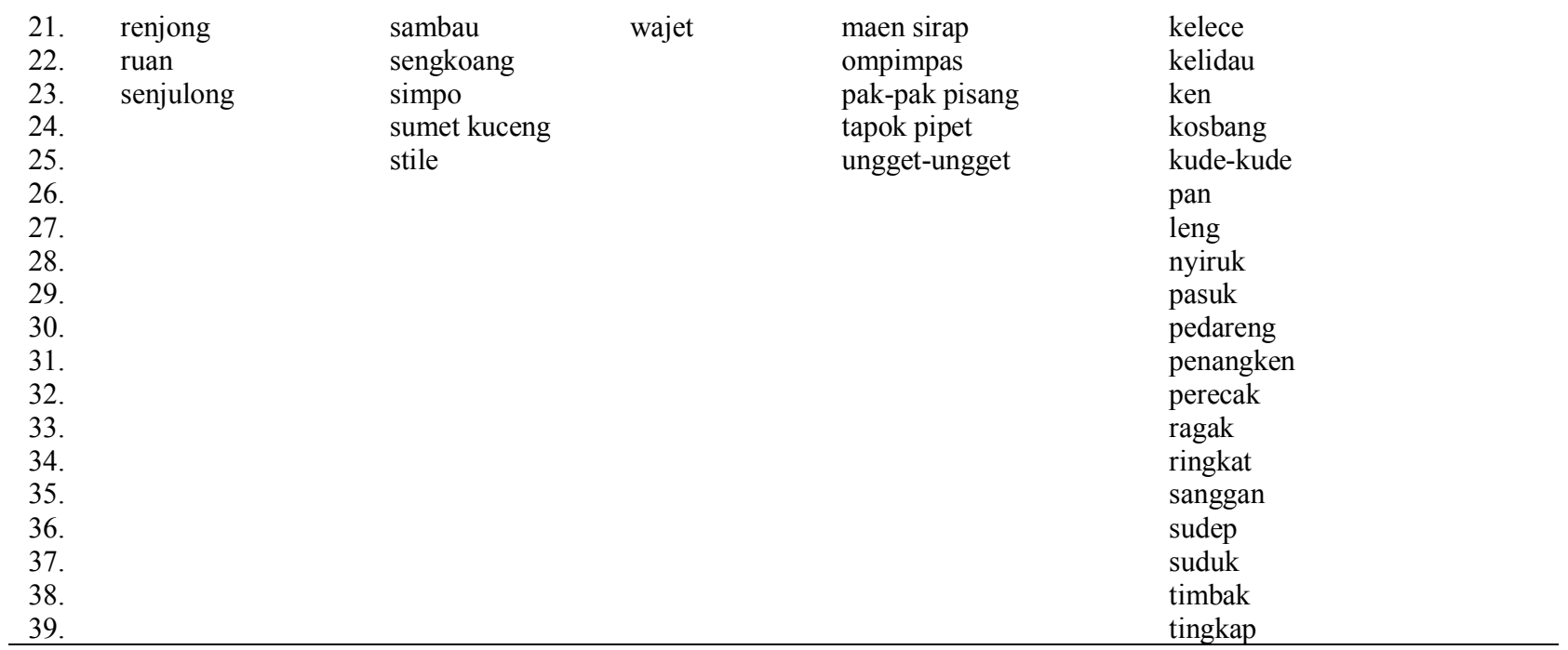

\section{Pemahaman Siswa Berdasarkan Gender}

Hasil yang diperoleh jika dilihat berdasarkan gender laki dan perempuan adalah sebagai berikut.

TABEL 2. Hasil Tes Pemahaman Siswa Berdasarkan Gender

\begin{tabular}{lll}
\hline No. & Siswa & Jumlah presentase pengetahuan seluruh kosakata \\
\hline 1. & Laki-laki & $71 \%$ \\
2. & Perempuan & $68 \%$ \\
\hline
\end{tabular}

Berdasarkan tabel di atas terdapat 52 orang sebagai sampel yang terdiri dari 33 sampel perempuan dan 19 sampel laki-laki dengan mengujikan 150 kosakata nama benda. Dapat dilihat bahwa perbedaan gender tidak memiliki pengaruh yang signifikan terhadap pengetahuan siswa mengenai kosakata nama benda bahasa Melayu Sukadana. Pemahaman siswa laki-laki hanya tinggi $3 \%$ daripada pengetahuan siswa perempuan. Dapat disimpulkan bahwa 29\% atau 43 kosakata nama benda tidak diketahui oleh siswa laki-laki dan 32\% atau 48 kosakata nama benda tidak diketahui oleh siswa perempuan.

TABEL 3. Hasil Tes Pemahaman Siswa Berdasarkan Gender Sesuai Pengelompokkan Kata Benda

\begin{tabular}{llcccccc}
\hline No. & Siswa & Hewan & Tumbuhan & Makanan & Mainan/Permainan & Alat Rumah Tangga & Penyakit \\
\hline 1. & Laki-laki & $81 \%$ & $54 \%$ & $60 \%$ & $83 \%$ & $71 \%$ & $76 \%$ \\
2. & Perempuan & $77 \%$ & $48 \%$ & $64 \%$ & $80 \%$ & $72 \%$ & $71 \%$ \\
\hline
\end{tabular}

Berdasarkan tabel di atas, rincian dari jumlah 150 kosakata, yaitu terdapat 23 kata hewan, 25 kata tumbuhan, 21 kata makanan, 25 kata mainan/permainan, 39 kata alat rumah tangga, dan 17 kata penyakit. Berdasarkan rincian tersebut siswa laki-laki hanya memahami : (1) 81\% kosakata hewan dan 19\% tidak memahami kosakata hewan atau hanya memahami 19 kosakata hewan dan tidak memahami 4 kosakata hewan, (2) 54\% 
kosakata tumbuhan dan 46\% tidak memahami kosakata tumbuhan atau hanya memahami 13 kosakata tumbuhan dan tidak memahami 12 kosakata tumbuhan, (3) $60 \%$ kosakata makanan dan 40\% tidak memahami kosakata makanan atau hanya memahami 13 kosakata makanan dan tidak memahami 8 kosakata makanan, (4) $83 \%$ kosakata mainan/permainan dan 17\% tidak memahami kosakata mainan/permainan atau hanya memahami 21 kosakata mainan/permainan dan tidak memahami 4 kosakata mainan/permainan, (5) $71 \%$ kosakata alat rumah tangga dan $29 \%$ tidak memahami kosakata alat rumah tangga atau hanya memahami 28 kosakata alat rumah tangga dan tidak memahami 11 kosakata alat rumah tangga, dan (6) $76 \%$ kosakata penyakit dan 24\% tidak memahami kosakata penyakit atau hanya memahami 13 kosakata penyakit dan tidak memahami 4 kosakata penyakit.

Selanjutnya, siswa perempuan hanya memahami : (1) $77 \%$ kosakata hewan dan $23 \%$ tidak memahami kosakata hewan atau hanya memahami 18 kosakata hewan dan tidak memahami 5 kosakata hewan, (2) 48\% kosakata tumbuhan dan 52\% tidak memahami kosakata tumbuhan atau hanya memahami 12 kosakata tumbuhan dan tidak memahami 13 kosakata tumbuhan, (3) $64 \%$ kosakata makanan dan 36\% tidak memahami kosakata makanan atau hanya memahami 13 kosakata makanan dan tidak memahami 8 kosakata makanan, (4) 80\% kosakata mainan/permainan dan 20\% tidak memahami kosakata mainan/permainan atau hanya memahami 20 kosakata mainan/permainan dan tidak memahami 5 kosakata mainan/permainan, (5) $72 \%$ kosakata alat rumah tangga dan $28 \%$ tidak memahami kosakata alat rumah atau hanya memahami 28 kosakata alat rumah tangga dan tidak memahami 11 kosakata alat rumah tangga, dan (6) 71\% kosakata penyakit dan 29\% tidak memahami kosakata penyakit atau hanya memahami 12 kosakata penyakit dan tidak memahami 5 kosakata penyakit.

Dapat dilihat bahwa secara keseluruhan pemahaman siswa terhadap kosakata nama benda tidak ada yang mencapai $100 \%$. Hal ini dilihat bahwa kisaran pemahaman tertinggi hanya mencapai $83-80 \%$ pada kosakata mainan/permainan dan pada pemahaman kosakata tumbuhan tergolong rendah kisaran 54-48\%.

\section{Pemahaman Siswa Berdasarkan Bahasa Ibu Bahasa Melayu Sukadana dan Bukan Berbahasa Ibu Bahasa Melayu Sukadana}

Berikut ini hasil tes kepada siswa berdasarkan bahasa ibu bahasa Melayu Sukadana dan bukan berbahasa ibu bahasa Melayu Sukadana.

TABEL 4. Hasil Tes Pemahaman Keseluruhan Siswa Berdasarkan Bahasa Ibu Melayu Sukadana dan Bukan Bahasa Melayu.

\begin{tabular}{clc}
\hline No. & \multicolumn{1}{c}{ Kategori Siswa } & $\begin{array}{c}\text { Jumlah Presentase Pengetahuan Seluruh } \\
\text { Kosakata }\end{array}$ \\
\hline 1. & Siswa berbahasa Ibu Melayu Sukadana & $72 \%$ \\
2. & $\begin{array}{l}\text { Siswa pindahan/ bukan berbahasa ibu } \\
\text { Melayu Sukadana }\end{array}$ & $63 \%$ \\
\hline
\end{tabular}

Berdasarkan tabel di atas terdapat 52 orang sebagai sampel yang terdiri dari 36 sampel Siswa berbahasa Ibu Melayu Sukadana dan 16 sampel Siswa pindahan/ bukan berbahasa ibu Melayu Sukadana dengan mengujikan 150 kosakata nama benda. Pemahaman siswa yang memiliki bahasa ibu bahasa Melayu Sukadana lebih tinggi 9\% daripada pengetahuan siswa yang bukan berbahasa ibu Melayu Sukadana. Dapat disimpulkan bahwa 28\% atau 42 
kosakata nama benda tidak diketahui oleh siswa berbahasa ibu bahasa Melayu Sukadana dan 37\% atau 55 kosakata nama benda tidak diketahui oleh siswa yang bukan berbahasa ibu Melayu Sukadana.

TABEL 5. Hasil Tes Pemahaman Siswa Berdasarkan Bahasa Ibu Sesuai Pengelompokkan Kata Benda

\begin{tabular}{|c|c|c|c|c|c|c|c|}
\hline No. & Siswa & Hewan & Tumbuhan & Makanan & Mainan/Permainan & $\begin{array}{c}\text { Alat rumah } \\
\text { tangga }\end{array}$ & Penyakit \\
\hline 1. & $\begin{array}{c}\text { Siswa berbahasa } \\
\text { Ibu Melayu } \\
\text { Sukadana }\end{array}$ & $81 \%$ & $53 \%$ & $69 \%$ & $82 \%$ & $74 \%$ & $76 \%$ \\
\hline 2. & $\begin{array}{c}\text { Siswa pindahan/ } \\
\text { bukan berbahasa } \\
\text { ibu Melayu } \\
\text { Sukadana }\end{array}$ & $73 \%$ & $45 \%$ & $49 \%$ & $78 \%$ & $66 \%$ & $66 \%$ \\
\hline
\end{tabular}

Berdasarkan tabel di atas, rincian dari jumlah 150 kosakata, yaitu terdapat 23 kata hewan, 25 kata tumbuhan, 21 kata makanan, 25 kata mainan/permainan, 39 kata alat rumah tangga, dan 17 kata penyakit. Berdasarkan rincian tersebut siswa berbahasa ibu Melayu Sukadana hanya memahami : (1) 81\% kosakata hewan dan 19\% tidak memahami kosakata hewan atau hanya memahami 19 kosakata hewan dan tidak memahami 4 kosakata hewan, (2) 53\% kosakata tumbuhan dan 47\% tidak memahami kosakata tumbuhan atau hanya memahami 13 kosakata tumbuhan dan tidak memahami 12 kosakata tumbuhan, (3) 69\% kosakata makanan dan 31\% tidak memahami kosakata makanan atau hanya memahami 14 kosakata makanan dan tidak memahami 7 kosakata makanan, (4) 82\% kosakata mainan/permainan dan 18\% tidak memahami kosakata mainan/permainan atau hanya memahami 20 kosakata mainan/permainan dan tidak memahami 5 kosakata mainan/permainan, (5) 74\% kosakata alat rumah tangga dan 26\% tidak memahami kosakata alat rumah tangga atau hanya memahami 29 kosakata alat rumah tangga dan tidak memahami 10 kosakata alat rumah tangga, dan (6) 76 \% kosakata penyakit dan $24 \%$ tidak memahami kosakata penyakit atau hanya memahami 13 kosakata penyakit dan tidak memahami 4 kosakata penyakit.

Selanjutnya, siswa yang bukan berbahasa ibu Melayu Sukadana hanya memahami : (1) 73\% kosakata hewan dan 27\% tidak memahami kosakata hewan atau hanya memahami 17 kosakata hewan dan tidak memahami 6 kosakata hewan, (2) 45\% kosakata tumbuhan dan 55\% tidak memahami kosakata tumbuhan atau hanya memahami 11 kosakata tumbuhan dan tidak memahami 14 kosakata tumbuhan, (3) 49\% kosakata makanan dan 51\% tidak memahami kosakata makanan atau hanya memahami 10 kosakata makanan dan tidak memahami 11 kosakata makanan, (4) 78\% kosakata mainan/permainan dan 22\% tidak memahami kosakata mainan/permainan atau hanya memahami 19 kosakata mainan/permainan dan tidak memahami 6 kosakata mainan/permainan, (5) 66 \% kosakata alat rumah tangga dan 34\% tidak memahami kosakata alat rumah atau hanya memahami 26 kosakata alat rumah tangga dan tidak memahami 13 kosakata alat rumah tangga, dan (6) 66\% kosakata penyakit dan 34\% tidak memahami kosakata penyakit atau hanya memahami 11 kosakata penyakit dan tidak memahami 6 kosakata penyakit.

Berdasarkan penjelasan di atas, dapat dilihat bahwa walaupun memiliki bahasa ibu Melayu Sukadana pemahaman siswa terhadap kosakata nama benda tidak ada yang mencapai $100 \%$. Kisaran pemahaman tertinggi 
hanya mencapai $82 \%$ pada siswa berbahasa ibu Melayu Sukadana dan $78 \%$ pada siswa yang bukan berbahasa ibu Melayu Sukadana terhadap kosakata mainan/permainan, sedangkan pemahaman terendah mencapai 53\% pada siswa berbahasa ibu Melayu Sukadana dan 45\% pada siswa yang bukan berbahasa ibu Melayu Sukadana terhadap kosakata tumbuhan.

\section{PENUTUP}

Berdasarkan penjelasan di atas, tidak ada siswa yang paham 100\% kosakata nama benda bahasa Melayu Sukadana, bahkan jika dilihat persentase secara keseluruhan siswa hanya paham 69\% kosakata nama benda bahasa Melayu Sukadana. Maka dari itu, penelitian mengenai pemahaman kosakata nama benda bahasa Melayu Sukadana pada siswa di Kecamatan Sukadana dapat menjadi tolok ukur untuk mengetahui tingkat pemahaman penutur muda terhadap kosakata tersebut. Dengan mengetahui tingkat pemahaman siswa, maka kita dapat melakukan proses pemertahanan bahasa, salah satunya dengan membuat glosarium. Kosakata yang telah dihimpun dapat dibuat glosarium sebagai bentuk pelestarian bahasa daerah agar bahasa daerah tersebut tidak punah.

\section{REFERENSI}

Alwi, Hasan dkk. 2010. Tata Bahasa Baku Bahasa Indonesia. Jakarta: Balai Pustaka.

Budiwiyanto, Adi. "Pendokumentasian Bahasa dalam Upaya Revitalisasi Bahasa Daerah yang Terancam Punah di Indonesia". http://badanbahasa.kemdikbud.go.id/lamanbahasa/artikel/1823/pendokumentasian-bahasa-dalamupaya-revitalisasi-bahasa-daerah-yang-terancam-punah-di-i. Artikel Badan Bahasa. Diakses 7 Juli 2019.

Chaer, Abdul dan Leonie Agustina. 2010. Sosiolinguistik Perkenalan Awal. Jakarta: Rineka Cipta.

Hidayat, Muhammad Ridho. 2009. (Online). "Pencarian dan Pemaknaan Metodologi" http://lontar.ui.ac.id/file?file=digital/127127-RB13M423p Pencarian\%20dan\%20pemaknaan-Metodologi.pdf. Jurnal Ilmiah. Diunduh 5 Maret 2014.

Jawak, Teresia M. 2014. Pemertahanan Bahasa Pakpak di Kecamatan Sumbul, Kabupaten Dairi, Provinsi Sumatera Utara. Skripsi Universitas Sumatera Utara.

Kesuma, Deli. 2014. Keterancaman Leksikon Ekoagraris dalam Bahasa Angkola/Mandailing: Kajian Ekolinguistik. Tesis Universitas Sumatera Utara.

Kridalaksana, Harimurti. 2008. Kamus Linguistik. Jakarta: PT Gramedia Pustaka Utama.

Nilamsari, Natalina. 2014. "Memahami Studi Dokumen Dalam Penelitian Kualitatif". Journal.moestopo.ac.id/index.php/wacana/article/download/143/pdf. Jurnal Fakultas Ilmu Komunikasi Universitas Prof. Dr. Moestopo. Diakses 7 Juli 2019.

Panggabean, Juli Indah. 2017. Pemertahanan Leksikon Kelautan dalam Bahasa Pesisir Sibolga Desa Pondok Batu Kecamatan Sarudik Ekolinguistik. Skripsi Universitas Sumatera Utara.

Susilana, Rudi. 2007. Modul Penelitian Kualitatif. Bandung: Universitas Pendidikan Indonesia.

Tondo, Fanny Henry. 2009. "Kepunahan Bahasa-Bahasa Daerah: Faktor Penyebab Dan Implikasi Etnolinguistis" Jmb.Lipi.Go.Id/Index.Php/Jmb/Article/Download/245/223. Jurnal Lipi. Diakses 7 Juli 2019.

Wahidmurni, 2017. "Pemaparan Metode Penelitian Kuantitatif”. http://repository.uin-malang.ac.id/1985/2/1985.pdf. Jurnal Fakultas Ilmu Tarbiyah dan Keguruan UIN Maulana Malik Ibrahim Malang. Diakses 2 Oktober 2019.

Widianto, Eko. 2018. "Pemertahanan Bahasa Daerah Melalui Pembelajaran dan Kegiatan Di Sekolah". Jurnal Universitas Muria Kudus. Diakses 7 Juli 2019. 